\title{
Educational technology to mediate care of the "kangaroo family" in the neonatal unit
}

\author{
Tecnologia educacional para mediar o acolhimento de "familiares cangurus" em unidade neonatal
} Tecnología educacional para mediar el acogimiento de "familiares canguro" en unidades neonatales

\author{
Marcia Helena Machado Nascimento', Elizabeth Teixeira" \\ 'Universidade do Estado do Pará. Belém, Pará, Brazil. \\ "Universidade Estadual do Rio de Janeiro. Rio de Janeiro, Brazil.

\begin{abstract}
How to cite this article:
Nascimento MHM, Teixeira E. Tecnologia educacional para mediar o acolhimento de "familiares cangurus" em unidade neonatal. Rev Bras Enferm [Internet]. 2018;71(Suppl 3):1290-7. [Thematic Issue: Health of woman and child] DOI: http://dx.doi.org/10.1590/0034-7167-2017-0156
\end{abstract}

Submission: 03-27-2017 Approval: 08-09-2017

\begin{abstract}
Objective: to validate the content of an educational technology in the form of a booklet developed to mediate care of family members of newborns hospitalized in a neonatal unit. Method: Methodological research with content validation. Data collected from October 2011 to February 2012; research developed in three steps: development, evaluation and adaptation. The study population was 15 judges, health professionals and other professionals. The participants answered a Likert-type questionnaire with 3 blocks of evaluative items. Data were analyzed statistically. Results: validation reached the results proposed in most responses (80\%); 16 items exceeded the parameter, 4 were equal to the score established and 2 were below the parameter. Conclusion: the content of educational technologies need to be validated. The booklet, after the evaluation, constitutes an adequate device to mediate care of the family members in the NICU.
\end{abstract}

Descriptors: Validation Studies; Neonatal Nursing; Educational Technology; Nursing; Health Education.

\section{RESUMO}

Objetivo: validar o conteúdo de uma tecnologia educacional tipo cartilha produzida para mediar o acolhimento de familiares de recém-nascidos internados em unidade neonatal. Método: Pesquisa de desenvolvimento metodológico, com validação de conteúdo. Dados coletados de outubro de 2011 a fevereiro de 2012; pesquisa desenvolvida em três fases: produção, avaliação e adequação. A população foi de 15 juízes, entre profissionais da saúde e de outras áreas. Estes responderam a um questionário com escala Likert de 3 blocos de itens avaliativos. Dados foram analisados estatisticamente. Resultados: a validação atingiu o valor proposto para a maioria das respostas $(80 \%) ; 16$ itens ultrapassaram a meta, 4 tiveram índices limítrofes e 2, abaixo do parâmetro. Conclusão: os conteúdos de tecnologias educacionais precisam ser validados. A cartilha, após a avaliação, constituise de um dispositivo adequado para mediar o acolhimento dos familiares em UTI neonatal.

Descritores: Estudos de Validação; Enfermagem Neonatal; Tecnologia Educacional; Enfermagem; Educação em Saúde.

\section{RESUMEN}

Objetivo: validar el contenido de una tecnología educativa tipo cartilla producida para mediar la acogida de familiares de recién nacidos internados en unidades neonatales. Método: Investigación de desarrollo metodológico, con validación de contenido. Los datos se recolectaron desde octubre de 2011 hasta febrero de 2012; la investigación se desarrolló en tres fases: producción, evaluación y adecuación. La población estaba compuesta por 15 jueces, entre profesionales de la salud y otras áreas. Estos respondieron a un cuestionario con escala Likert de 3 bloques de ítems evaluativos; los datos se analizaron estadísticamente. Resultados: la validación alcanzó el valor propuesto para la mayoría de las respuestas (80\%); 16 elementos superaron la meta, 4 tuvieron índices limítrofes y 2 quedaron por debajo del parámetro. Conclusión: es necesario que se validen los contenidos de las tecnologías educacionales. La cartilla, tras la evaluación, se ha constituido en un dispositivo adecuado para mediar el acogimiento de los familiares en UCl neonatales. Descriptores: Estudios de Validación; Enfermería Neonatal; Tecnología Educacional; Enfermería; Educación En Salud. 


\section{INTRODUCTION}

The term technologies have a broad meaning; it refers to techniques, methods, instruments, procedures, tools, equipment and settings that enable one or several outcome/processes. In this context, educational technologies are understood as any instrument used in the relationship teacher-student, educator-apprentice, nurse-patient to accomplish and facilitate an educational process ${ }^{(1)}$.

The educational technologies used in nursing are understood as a philosophical foundation for personal development. They are characterized by new teaching strategies, theories, researches, concepts and techniques for updating education, which can help the educator in finding innovative ways to exchange knowledge, facilitate the learning process and contribute to educational advancement ${ }^{(2)}$.

In the context of the neonatal ICU, educational technologies are seen as unconventional techniques for neonatal nursing care. However, when allied to scientific knowledge and associated with the daily needs of a neonatal intensive care unit (NICU), they can bring a fresh look to the care-education process.

Many NICUs have already taken on the important role of caring for family members and guiding them to reestablish their relationship with the child, helping them through the stressful period of hospitalization. It is essential that the family accompanies the child during this phase, participating in the care, so that they are able to take care of the child after hospital discharge, making everyone feel safe in this aspect ${ }^{(3)}$.

The experience with family members of newborns in the $\mathrm{NICU}$ in several cities in the state of Pará, mainly with riverside population - where services are accessed by canoes and boats, communication is by radio message and where there is no hospital environment for the hospitalization of newborns - revealed that the difficulties of these family members are greater than of those residing in the state capital. Therefore, the orientations need to contemplate different needs and family profiles.

In this sense, it is necessary to seek strategies to better care for these families. For this purpose, it is necessary to develop and validate educational technologies containing information on the importance of the interaction-action of these relatives with the newborn/health team in neonatal environment, based on the conception of kangaroo care.

The kangaroo care method prioritizes the care to low birth weight newborns during their stay in the NICU, but does not exclude other cases. Its innovative actions can be applied to all newborns in neonatal therapy and their respective family members, since they also experience different situations during hospitalization, some of which are similar to those of low birth weight newborns. Nursing should be aware of its role in neonatal care and base their actions on the norms of the method for caring for and educating the newborn and the family.

Health education with the "kangaroo family" in the NICU is indispensable in terms of care, service, interpersonal relationships and the family-newborn-nursing team interaction, as it creates possibilities for reflection and open spaces for decision-making. The nursing care is linked to these aspects, since its intention is therapeutic, concerned with the other and based on science and technologies.
Content validation of an instrument is necessarily based on a judgment and indicates to what extent the instrument has an appropriate sample of items to measure the specific construct and adequately cover its domain ${ }^{(4)}$. It tests the ability of the items to represent adequately all dimensions of the content addressed in the instrument.

In this context, validity in the dimension of educational technologies can be defined as the degree to which an educational technology is appropriate to mediate what it is supposed to mediate. Thus, when an educational technology in health $(E T H)$ is submitted to the validation procedure, in reality, it is not the ETH itself that is being validated, but the purpose for which it will be used ${ }^{(1)}$.

Thus, this study becomes relevant as it leads to the production of a printed educational technology, specifically a booklet for "kangaroo families". The booklet enables family care mediated by information that answers doubts and minimizes the impact and feelings of fear caused by the hospitalization in the neonatal intensive care unit.

The use of educational technologies in the NICU must consider the transformations that they can bring, and thus must include the relevant characteristics of the target audience in order to properly develop any professional activity.

\section{OBJECTIVE}

To validate the content of an educational technology in the form of a booklet, produced to mediate care of family members of newborns hospitalized in the intensive care unit.

\section{METHOD}

\section{Ethical aspects}

According to ethical-legal precepts, the research was approved by the Research Ethics Committee of the State Public Foundation Hospital de Clínicas Gaspar Viana.

\section{Type of study}

This is a technology validation and methodological study, carried out from October 2011 to February 2012. The focus of the study was the content validation of an educational technology in the form of a booklet, aimed at mediating the care of family members of newborns in the NICU based on the kangaroo care method.

\section{Methodological procedures}

Methodological research develops instruments and often involves complex and sophisticated methods. It refers to investigations of methods for obtaining, organizing data and addressing the development, validation and evaluation of research tools and methods ${ }^{(4)}$.

The validity can be evaluated through two aspects: validation of the content of an instrument and validation of semantics ${ }^{(5)}$. This study will only present the content validation.

Content validation implies the thorough analysis of the content of an instrument, in order to verify that the proposed items constitute a representative sample of the subject to be 
measured $^{(6)}$. This means that content validation must establish whether the content of a measuring instrument effectively addresses all the requirements for measuring a particular phenomenon $^{(7)}$.

An instrument is valid when multiple measures are employed in order to respond to a single research question. A greater convergence of results after the use of several techniques provides greater reliability and validity in the results of the study. Agreement between the expert judges will be set at $80 \%$, based on the values used in other studies ${ }^{(6,8-9)}$.

\section{Scenario study}

The validation process was carried out in different places, but was based on the Neonatal Intensive Care Unit (NICU) of the State Public Foundation Hospital Clínicas Gaspar Viana - Belém-PA.

\section{Collection and organization of data}

The judges were personally invited to participate and, afterwards, received a letter of invitation; when accepting it, they filled the Informed Consent Form and received a copy of the booklet to be evaluated, along with the respective evaluation instrument to be returned within a period of 10 days. Judges had the function of judging the booklet regarding clarity, comprehensibility or redundancy and adequacy of the behavioral representation of the items.

- Phase 1: Development of educational technology. The elaboration of the educational technology (version 1) corresponded to the selection of the content based on literature on neonatal care, care and family member in the NICU. The instrument was based on the recommendations of the Kangaroo Care Manual, which focus on neonatal care practices aimed at promoting an affective bond and normal neuropsychomotor development of newborns admitted to intensive care ${ }^{(10)}$. In addition, the parents' frequent doubts regarding their child's hospitalization in the NICU, discharge and home care were taken into consideration.

After the selection of the content, the development of the technology started through typing and illustrating the content of the first version of the booklet. Some photos were copied from the Internet and others captured in the NICU itself, the study scenario, without portraying human beings; finally, the booklet was printed. Figure 1 summarizes the steps in the design of the educational technology.

- Phase 2: Evaluation of the booklet by judges. The version 1 was initially evaluated by judges from other areas: social communicator, pedagogue, graphic designer and art educator. The booklet was revised and updated based on the aforementioned contributions. Version 3 was then made available to the judges in the health area. The data collection instrument of the judges was a questionnaire, organized in Likert scale, containing three blocks of evaluative items referring to the content of the educational material. Block I was composed of 5 evaluative items referring to the objectives, which correspond to purposes, goals or ends that are desired to be achieved with the use of the educational technology. Block II was composed of 12 evaluative items regarding structure and organization, which refers to how the orientations are presented. This includes general organization, structure, presentation strategy, consistency and formatting. Block III was composed of 5 evaluative items related to relevance, which refers to the characteristics that evaluate the degree of educational significance.

All the judges answered the questionnaire, considering the scores used for judging the booklet (1, 2, 3 or 4) and followed a scale containing four grades of assessment: totally adequate (TA), adequate (A), partially adequate (PA) and inadequate (I). Figure 2 summarizes the evaluation of the judges.

The procedure for the content validation and analysis was based on Pasquali's framework ${ }^{(11)}$. The answers, that indicated a specific level of agreement or disagreement with each statement, were added up, generating a total score. The judges could also describe their opinions ${ }^{(4)}$.

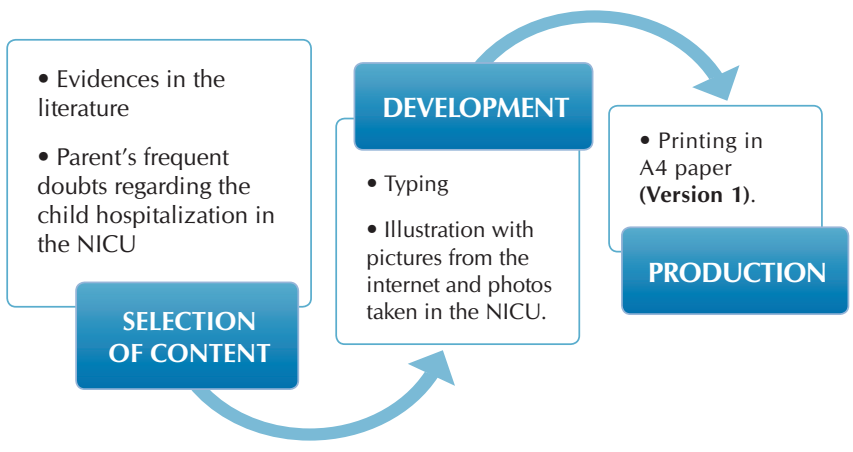

Figure 1 - Figure with the steps of the technology design

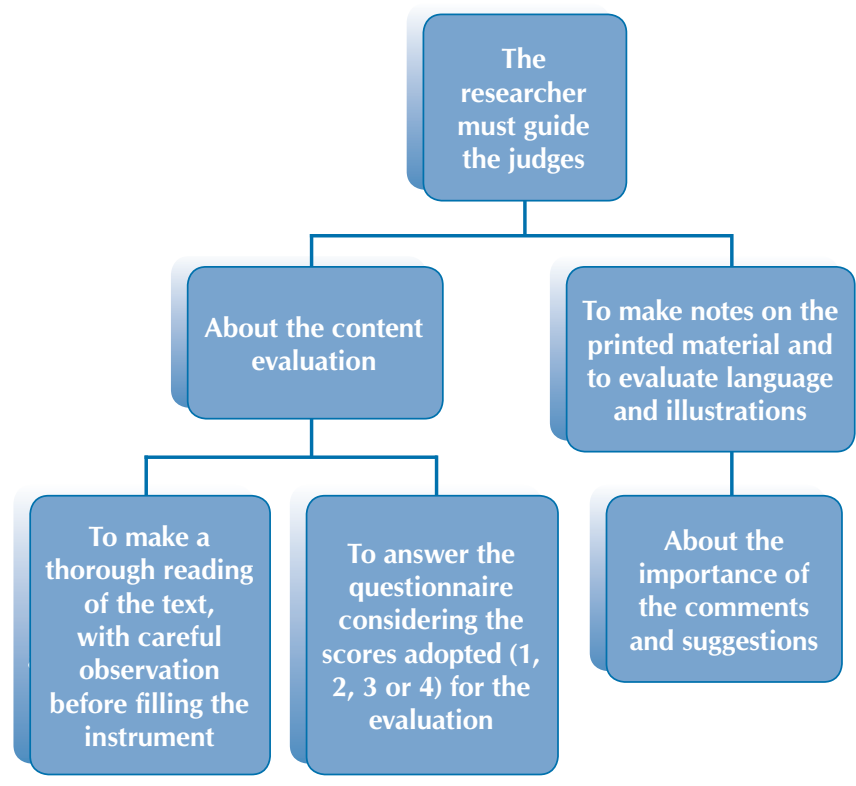

Figure 2 - Diagram of the summary of the judges' evaluation 


\section{Data analysis}

For this analysis, the adequacy of the behavioral representation of the items was calculated, meaning the items were judged based in whether or not they referred to the topic in question. The analysis of the adequacy of the behavioral representation of the items is related to the score calculated, which is equivalent to the arithmetic mean of the scores of the item analyzed by the judges ${ }^{(12)}$. For this analysis, the response options TA, A, PA and I were grouped: TA and A were considered positive responses $(+1)$, and PA (zero) and I were considered negative responses $(-1)$. The response of each judge could vary from negative $(-1)$ to positive $(+1)$, and the more responses close to +1 , the greater the agreement between the judges' answers regarding the pertinence of the item (agreement index).

From the answers of the judges, the levels of agreement were calculated, which varied between -1 and +1 . After that, each item was analyzed: analysis of the means obtained, and of the answers of most of the items that obtained means equal or above the index of $80 \%$ (positive means); the items that obtained means lower than expected were modified. The booklet was updated and prepared for the next moment (version 4).

The data collected from the instruments were organized to verify the valuation of the majority of the answers, in order to infer whether or not there was a significant indication of disagreement in each of the blocks of the form ${ }^{(1)}$. The value of the statistic corresponds to the arithmetic mean of the scores of the items analyzed by the expert judges ${ }^{(9)}$.

The items that obtain a level of agreement between expertjudges above the value adopted are considered valid. This is considered a decision criterion for the pertinence and/or acceptance of each item ${ }^{(8-9)}$.

- Phase 3: Adaptation of the educational technology: Elaboration of the last version of the booklet (version 5). It consisted of the modifications in the texts and images of the booklet based on the judges' considerations, aiming to give quality to the instrument to mediate the careeducation of the relatives in the NICU.

\section{RESULTS}

\section{Profile of the Participants}

The study population consisted of 15 professionals who were responsible for the content validation. The professionals selected as judges in the health area were: 6 nurses, 3 neonatal intensive care physicians, 1 occupational therapist and 1 psychologist. The professionals from other areas were 1 pedagogue, 1 graphic designer, 1 art educator and 1 social communicator.

\section{Content Validation}

- BLOCK 1: Objectives refers to purposes, goals or ends to be achieved with the use of the booklet. In the evaluation of the responses of this block, there were 50 answers $(66.66 \%)$ TA, $20(26.66 \%)$ A, 5 PA $(6.66 \%)$ and 0 I $(0 \%)$. According to the options of answers, the scores TA, A and P add up to 75 , that is, $100 \%$ of the answers were valid and $70(93.32 \%)$ were TA and $\mathrm{A}$.

Regarding the level of agreement in this block, the lowest mean obtained was 0.80 , and the highest was 0.100 , meeting the value previously set.

- BLOCK 2: Structure and presentation refers to how the orientations are presented to the target population, their organization, structure, consistency and formatting. In this aspect, the answers of the judges were: $85(48.85 \%)$ TA, $59(33.90 \%)$ A, 26 (14.94\%) PA and $4(2.29 \%)$ I. Of the $174(100 \%)$ answers obtained for all items in this block, $144(82.75 \%)$ were evaluated as TA and A.

Table 1 - Answers obtained from expert judges according to the objectives, Belém, Pará, Brazil, 2012

\begin{tabular}{|c|c|c|c|c|}
\hline \multirow[t]{2}{*}{ Items } & & $\begin{array}{l}\text { core } \\
x 10 \\
\text { enta }\end{array}$ & $\begin{array}{l}=1 \\
+\mathrm{A} \\
\text { y es }\end{array}$ & \multirow{2}{*}{$\begin{array}{c}\text { Level of agreement per item } \\
\text { TA + A x } 100 \\
\text { Total of judges }\end{array}$} \\
\hline & TA & A & PA & \\
\hline
\end{tabular}

Block 1: Objectives:

1.1 Coherence between information/content and the daily needs of the relatives in the NICU

1.2 Importance of information/content for the quality of the care provided to family members in the NICU

1.3 Instigates behavior and attitude changes in family members of the hospitalized newborn

1.4 The ETH can be disseminated in the scientific area

1.5 The ETH meets the objectives of the institutions that have a NICU and care for the families.

Scores per block

Percentage per block

$\begin{array}{ccccc}10 & 4 & 1 & 0 & 0.93 \\ 13 & 2 & 0 & 0 & 0.100 \\ 9 & 5 & 1 & 0 & 0.93 \\ 8 & 4 & 3 & 0 & 0.80 \\ 10 & 5 & 0 & 0 & 0.100 \\ 50 & 20 & 5 & 0 & \\ 66.66 & 26.66 & 6.66 & 0 & \end{array}$

Total percentages

99.99

Note: Scores TA = Totally adequate; $A=$ Adequate; $P A=$ Parcially adequate; $I=I$ nadequate. NICU $=$ Neonatal Intensive Care Unit. ETH=Educational Technology in Health 
Table 2 - Answers obtained from the expert judges regarding structure and presentation, Belém, Pará, Brazil, 2012

\begin{tabular}{|c|c|c|c|c|}
\hline \multirow[t]{2}{*}{ Items } & \multicolumn{3}{|c|}{$\begin{array}{c}\text { Scores }(N=15) \\
\text { Score } x 100 / T A+A+P A= \\
\text { Percentage per score }\end{array}$} & \multirow[t]{2}{*}{$\begin{array}{c}\text { Level of agreement per item } \\
\text { TA }+A \times 100 \\
\text { Total of judges }\end{array}$} \\
\hline & TA & A & $\mathbf{P}$ & \\
\hline
\end{tabular}

Block II: Structure and presentation

2.1. Adequacy of the booklet for family members in the NICU

2.2 Clarity and objectivity of messages

2.3 Presentation of scientifically correct information

2.4 Adequacy of the material to the sociocultural level of relatives in the NICU

2.5 Logical sequence of the content

2.6. Structure of the information regarding grammar and spelling

2.7. Correspondence between the writing style and the level of knowledge of the family members

2.8. Coherence of the information in the cover, back cover, summary, acknowledgments and/or presentation

2.9. Adequate size of title and topics

2.10 The illustrations are expressive and sufficient

2.11. Appropriate material (paper/print)

2.12 Adequate number of pages

Score per block

Percentage per block

Total Percentage

$\begin{array}{ccccc}10 & 4 & 1 & 0 & 0.93 \\ 4 & 9 & 2 & 0 & 0.86 \\ 7 & 6 & 2 & 0 & 0.86 \\ 6 & 7 & 2 & 0 & 0.86 \\ 8 & 5 & 2 & 0 & 0.86 \\ 6 & 5 & 2 & 2 & 0.73 \\ 5 & 7 & 3 & 0 & 0.80 \\ 8 & 4 & 2 & 1 & 0.80 \\ 8 & 4 & 2 & 1 & 0.80 \\ 5 & 6 & 4 & 0 & 0.73 \\ 8 & 5 & 2 & 0 & 0.86 \\ 10 & 3 & 2 & 0 & 0.86 \\ 85 & 59 & 26 & 4 & \\ 48.85 & 33.90 & 14.94 & 2.29 & \end{array}$

Note: Scores TA=Totally adequate; $A=$ Adequate; $P A=$ Partially adequate; $I=$ Inadequate. NICU=Neonatal Intensive Care Unit

Table 3 - Answers obtained from the expert judges regarding the relevance of the instrument, Belém, Pará, Brazil, 2012

\begin{tabular}{|c|c|c|c|c|c|}
\hline \multirow[t]{2}{*}{ Items } & \multicolumn{4}{|c|}{$\begin{array}{c}\text { Scores }(N=15) \\
\text { Score } x 100 / T A+A+P A= \\
\text { Percentage per score }\end{array}$} & \multirow{2}{*}{$\begin{array}{c}\text { Level of agreement per item } \\
\text { TA }+A x 100 \\
\text { Total of judges }\end{array}$} \\
\hline & TA & A & $\mathbf{P}$ & $\mathbf{I}$ & \\
\hline \multicolumn{6}{|l|}{ Block II: Relevance } \\
\hline 3.1 Topics covered key aspects that need to be strengthened & 13 & 2 & 0 & 0 & 0.100 \\
\hline $\begin{array}{l}\text { 3.2 The material allows the transfer and generalization of knowledge to } \\
\text { different contexts (neonatal intensive care unit) }\end{array}$ & 11 & 4 & 0 & 0 & 0.100 \\
\hline 3.3 The booklet proposes the construction of knowledge & 11 & 4 & 0 & 0 & 0.100 \\
\hline $\begin{array}{l}\text { 3.4 The material addresses the subjects that family members in the NICU } \\
\text { need to know }\end{array}$ & 12 & 2 & 1 & 0 & 0.93 \\
\hline 3.5 The booklet is suitable for use by any family member in the NICU & 10 & 4 & 1 & 0 & 0.93 \\
\hline Scores per block & 57 & 16 & 2 & 0 & \\
\hline Percentage per block & 76 & 21.33 & 2.66 & 0 & \\
\hline Total percentage & & & 99.99 & & \\
\hline
\end{tabular}

Note: $S$ cores $T A=$ Totally adequate; $A=$ Adequate; $P A=$ Partially adequate; $I=$ Inadequate. NICU=Neonatal Intensive Care Unit

The level of agreement in this block obtained two means of 0.73 , value below the proposed index. However, most of the means exceeded the expected value.

- BLOCK 3: Relevance refers to the characteristics that determine the degree of significance of the booklet. The responses were: 57 (76\%) TA, 16 (21.33\%) A, 2 (2.66\%) PA and 0
$(0 \%)$ I. Therefore, from $75(100 \%)$ options for all items in this block, $73(97.33 \%)$ were evaluated as TA and A. For this block, the majority of the positive mean were 0.100 , giving an agreement level above the mean index of $80 \%$.

The sum of all TA scores resulted in a total of 192, and the sum of the A scores resulted in a total of 95 . This confirms the 
propensity for consistent responses between the judges regarding the answers TA (59.25\%) and A (29.32\%). Of the 22 items of the questionnaire presented in the three validation tables, only four obtained an I (inadequate) score, characterizing greater agreement among the judges regarding the items evaluated.

The results of all items of the three tables show the superiority of the evaluations TA and A. The percentages of agreement between the blocks showed values from $93 \%$ to $100 \%$, confirming that the booklet reached the level of significance for validation.

As for the result of the educational technology itself, it is validated by the judges as an illustrated booklet, with textual information and some photographs produced by the author of this article with authorship.

The booklet has 20 pages. In the pre-text, there are: an illustrated cover with the title "Booklet to mediate care-education in the reception of the 'kangaroo family' in a neonatal unit"; a second cover; a presentation to family members about the NICU based on the kangaroo care method. In the text, the development of the 3 topics with related images can be highlighted: 1) the NICU environment (definition of NICU, presentation of the professionals working in the sector and the equipment used for neonatal care and preparation of the environment according to the kangaroo care method); 2) Caring for the newborn according to the kangaroo care method (steps since the care before entering the NICU until the information that the family should know to continue this care at home); 3) Discharge orientations. In the post-text of the booklet is the fourth cover, which presents the technical information and the authorship. The booklet ends with the back cover, which presents the educational institutions involved.

\section{DISCUSSION}

Considering these results, the first block obtained agreement among the judges. This block addresses the purpose of the booklet, which concerns the goal that should be achieved with the educational material, which is the care-education in the care of the "kangaroo family" in the NICU according to the kangaroo care method. According to the acceptance of the items of this block, the booklet was considered adequate regarding the objective of this evaluation. The level of agreement reached the value proposed in this study.

The study "Technology as a foundation of neonatal care" proposes a critical and reflexive evaluation about the use of technology in neonatal care and discusses the possibility of accepting measures and strategies that value and respect human life in its whole dimension, ensuring an individualized care and personifying the newborn and his family ${ }^{(13)}$.

In the second block the acceptance found was of $82.75 \%$, which corresponds to a majority of the answers totally adequate and adequate. However, two items were judged inadequate: item "2.6", that refers to the structure, grammar and spelling of the information and item "2.10", which addresses the sufficiency and expressiveness of the illustrations. The judges pointed out spelling errors, making the adequate corrections, and confirmed the booklet as appropriate to be used with the families.
Still, after the suggestions were accepted, the booklet was sent to a language review.

The photographic expressions considered insufficient were modified and sent to the advertising professional for alterations in the layout and photographs. It is worth emphasizing that the Portuguese language is a common subject for all professionals, unlike information technology, which is a specific discipline.

In the validation process of instruments submitted to experts in the subject, it is appropriate to suggest, correct, add or modify items ${ }^{(6)}$. Each item has its value so that the educational material can reach the target audience in an appropriate way.

Anthropological research emphasizes that visual imagery is a medium of communication that has a great influence on social, moral and ethical values, constituting a fully accepted and understood code. Posters, booklets, manuals, brochures and folders show through symbols and signs the messages intended to be passed on to the target audience, but can only reach their purpose if they are fully integrated with the social imaginary ${ }^{(14)}$.

In the third block, the booklet was considered valid regarding its relevance. The judges' suggestions express satisfaction for the initiative and indicate that the booklet has great probability of optimizing the care of family members in the NICU; some judges suggested that the unit team members could read the booklet along with family members and not just hand them over. One judge commented that educational technology is a breakthrough in neonatal nursing in the state. In general, the agreement between them exceeded expectations.

Understanding the design of technology in nursing is a challenge for a profession with focus on the individual. However, technology cannot be understood as a paradigm of care opposed to the human, but, above all, it must be considered as an agent and object that works in function of the human person. Technology can be a humanizing factor, even in the most technologically intense areas of health care ${ }^{(15)}$.

As for the level of agreement, some items had a negative evaluation of 0.73 , an index below the proposed value (0.8). These responses signaled the need for alterations of these items in the final booklet, which were made without bias in the validation. It is important to note that some of the answers with a score equal to or above the criterion also included adjustments for a better presentation of the booklet, according to the judges' opinions.

\section{Limitations of the study}

As a limitation of the study is the fact the educational technology was constructed based on a broad literature review, but, in terms of contextualization, it considered the frequent doubts of the parents attended in a neonatal unit, the researcher's place of work, located in a general hospital in the city of Belém.

\section{Contributions to the areas of nursing, health or public policy}

The development of educational technology is an advance for health education activities with families of children attending NICUs, since it can mediate the educational activity and the reception given by nurses and other health professionals to these families. The intention is not to replace the professional activity, but to provide an instrument that can facilitate the educational action. 
Therefore, the booklet should be disseminated both in the academic community and among nurses and other professionals. Daily educational activities addressing knowledge and practices based on the kangaroo method for families of children hospitalized in the NICU should also be implemented.

In this perspective, the use of educational technologies is considered a care-education resource. Thus, the educational technology contributes as a device to be used in health education activities.

\section{FINAL CONSIDERATIONS}

Health education through a printed technology is an innovative action in the NICU, especially when related to the care-education provided to family members of hospitalized newborns.

The general objective of the validation of a booklet to care of family members of newborns admitted in the intensive care unit was reached. The validation process of the booklet was not easy, however, it is indispensable for the qualification of a printed educational material. The first challenge was the selection of the professionals participating in the research (judges). The second was the difficulty some judges had to understand the judging process. Some opined only through the scores and felt uncomfortable to describe the comments/suggestions.

In this aspect, the objectivity of the data collection is important. It is necessary to facilitate contact for the clarification of doubts, and the researcher must be prepared to make the necessary changes in the versions of the booklet until consensus is reached.

It is important to not be attached to the first version of the booklet, which will facilitate the analysis and the modifications. The adequacy of the texts to the language, culture and knowledge of the target audience is complex and requires skill with the use of scientific language, hence the importance of a pedagogue as judge in this process and family members as the target audience of the booklet.

The images were very well evaluated, demonstrating the power of communication of the illustrations. The results reveal that the booklet is a statistically valid instrument, since it reached a level of agreement above the proposed $80 \%$. This means that, in the process of validation of the technology, the booklet produced was considered adequate to mediate care of "kangaroo family" in the neonatal intensive care unit, according to the evaluation of expert judges. The instrument was considered valid to use with the target audience, which is demonstrated by the consensus among the study participants.

The use of the booklet technology is considered valid to mediate the care-education of the nurses in the NICU in various situations. However, it should be noted that it is necessary to submit any technology produced to the validation process in order to recognize the communication and the information disclosed to support the process of health education.

In this sense, the nursing team should use the booklet as an educational device in the NICU to receive the "kangaroo family". This term was created to encourage mothers, fathers and other family members to practice skin-to-skin contact with their baby. Regarding teaching and research, a validated, innovative and ready to use educational technology based on the kangaroo method emerged in this study. After registration of authorship and reproduction, it will be made available to the relatives of newborns admitted to the NICU.

The expectation, in this sense, is that the booklet for "kangaroo families" will make nurses working in the NICU more aware about the importance of including the family as a care unit. Health education has no right place or time to be used. In short and without intention to conclude, we emphasize that the production and validation of educational technologies need to be considered a nursing process.

\section{REFERENCES}

1. Teixeira E, Mota VMSS, (Orgs.). Tecnologias educacionais em foco. São Paulo, SP: Difusão; 2011.

2. Nietsche EA, Backes VMS, Colomé CLM, Ceratti RN, Ferraz F. Tecnologias educacionais, assistenciais e gerenciais: uma reflexão a partir da concepção dos docentes de enfermagem. Rev Latino-Am Enferm[Internet]. 2005[cited 2012 Apr 19];18(3):344-53. Available from: http://www.scielo.br/pdf/rlae/v13n3/v13n3a09.pdf

3. Tamez RN. Enfermagem na UTI Neonatal: assistência ao recém-nascido de alto risco. 4 ed. Rio de Janeiro, RJ: Guanabara Koogan; 2013.

4. Polit DF, Beck CT. Fundamentos de Pesquisa em enfermagem: avaliação de evidências para as práticas da enfermagem. 7a ed. Porto Alegre (RS): Artmed; 2011. 669 p.

5. Martins GA. Sobre Confiabilidade e validade. Rev Bras Ges Neg [Internet]. 2006 [cited 2012 Apr 19];8(20):1-12. Available from: http://www.spell.org.br/documentos/ver/6471/sobre-confiabilidade-e-validade

6. Perroca MG. Development and content validity of the new version of a patient classification instrument. Rev Latino-Am Enfermagem [Internet]. 2011 [cited 2012 Jan 15];19(1):58-66. Available from: http://www.scielo.br/pdf/rlae/v19n1/pt_09.pdf

7. Bellucci Jr JA, Matsuda LM. Construção e validação de instrumento para avaliação do Acolhimento com Classificação de Risco. Rev Bras Enferm [Internet]. 2012 [cited 2015 Sep 15];65(5):751-7. Available from: http://www.scielo.br/pdf/reben/v65n5/06.pdf

8. Oliveira MS, Fernandes AFC, Sawada NO. Manual educativo para o autocuidado da mulher mastectomizada: um estudo de validação. Texto Contexto Enferm [Internet]. 2008 [cited 2012 Jan 15];17(1):115-23. Available from: http://www.scielo.br/pdf/tce/ v17n1/13.pdf 
9. Moreira APA, Sabóia VM, Camacho ACLF, Daher DV, Teixeira E. Jogo educativo de administração de medicamentos: um estudo de validação. Rev Bras Enferm [Internet]. 2014 [cited 2015 Sep 15];67(4):528-34. Available from: http://www.scielo.br/pdf/reben/ v67n4/0034-7167-reben-67-04-0528.pdf

10. Brasil. Ministério da Saúde. Secretaria de Atenção a Saúde. Departamento de Ações Programáticas Estratégicas. Atenção humanizada ao recém-nascido de baixo peso: Método Canguru [Internet]. - 2ª . ed. - Brasília: Editora do Ministério da Saúde (Serie A. Normas e Manuais Técnicos). 2011[cited 2015 Sep 15].204p. Available from: http://bvsms.saude.gov.br/bvs/publicacoes/atencao_humanizada_ recem_nascido_canguru.pdf

11. Pasquali L. Instrumentação psicológica: fundamentos e práticas. Porto Alegre, Brasil: Artmed. 2010. 182 p.

12. Teixeira E, Siqueira AA, Silva JP, Lavor LC. Cuidados com a saúde da criança e validação de uma tecnologia educativa para famílias ribeirinhas. Rev Bras Enferm[Internet]. 2011[cited 2012 Apr 30];64(6):1003-9. Available from: http://www.scielo.br/pdf/reben/ v64n6/v64n6a03.pdf

13. Sá Neto JA, Rodrigues BMRD. Tecnologia como fundamento do cuidar em neonatologia. Texto Contexto Enferm [Internet]. 2010[cited 2012 Jun 30];19(2):372-7. Available from http://www.scielo.br/pdf/tce/v19n2/20.pdf

14. Oliveira VLB, Landim FLP, Collares PM, Mesquita RB, Santos ZMSA. Modelo explicativo popular e profissional das mensagens de cartazes utilizados nas campanhas de saúde. Texto Contexto Enferm [Internet]. 2007[cited 2012 Apr 30];16(2):287-93. Available from: http://www.scielo.br/pdf/tce/v16n2/a11v16n2

15. Barbosa SFF, Dal Sasso GTMD, Berns I. Enfermagem e tecnologia: análise dos grupos de pesquisa cadastrados na plataforma Lattes do CNPq. Texto Contexto Enferm [Internet]. 2009[cited 2015 Sep 15];18(3):443-8. Available from: http://www.scielo.br/pdf/tce/ v18n3/a06v18n3.pdf 